\title{
Irrigation scheduling strategies for cotton to cope with water scarcity in the Fergana Valley, Central Asia
}

\author{
L.S. Pereira ${ }^{a, *}$, P. Paredes ${ }^{a}$, E.D. Cholpankulov ${ }^{b}$, O.P. Inchenkova ${ }^{b}$, P.R. Teodoro ${ }^{a}$, \\ M.G. Horst ${ }^{c}$ \\ ${ }^{a}$ Agricultural Engineering Research Center, Institute of Agronomy, Technical University of Lisbon, Tapada da Ajuda, Lisbon, Portugal \\ ${ }^{\mathrm{b}}$ Scientific Information Centre of the Interstate Coordination Water Commission of Central Asia (SIC-ICWC), B.11, Karasu-4, Tashkent \\ 700187, Uzbekistan \\ ${ }^{c}$ Central Asian Scientific Research Institute of Irrigation (SANIIRI), B.11, Karasu-4, Tashkent 700187, Uzbekistan
}

\section{A R T I C L E I N F O}

Article history:

Received 19 May 2008

Received in revised form

24 October 2008

Accepted 24 October 2008

Published on line 16 December 2008

Keywords:

Irrigation requirements

Deficit irrigation

Water savings

Water productivity

Economic water productivity

\begin{abstract}
A B S T R A C T
The Central Asian countries face high water scarcity due to aridity and desertification but excess water is often applied to the main irrigated crops. This over-irrigation contributes to aggravate water scarcity problems. Improved water saving irrigation is therefore required, mainly through appropriate irrigation scheduling. To provide for it, after being previously calibrated and validated for cotton in the Fergana region, the irrigation scheduling simulation model ISAREG was explored to simulate improved irrigation scheduling alternatives. Results show that using the present irrigation scheduling a large part of the applied water, averaging $20 \%$, percolates out of the root zone. Several irrigation strategies were analyzed, including full irrigation and various levels of deficit irrigation. The analysis focused a threeyear period when experiments for calibration and validation of the model were carried out, and a longer period of 33 years that provided for an analysis considering the probabilities of the demand for irrigation water. The first concerned a wet period while the second includes a variety of climatic demand conditions that provided for analyzing alternative schedules for average, high and very high climatic demand. Results have shown the importance of the groundwater contribution, mainly when deficit irrigation is applied. Analyzing several deficit irrigation strategies through the respective potential water saving, relative yield losses, water productivity and economic water productivity, it could be concluded that relative mild deficits may be adopted. Contrarily, the adoption of high water deficit that produce high water savings would lead to yield losses that may be economically not acceptable.
\end{abstract}

(C) 2008 Elsevier B.V. All rights reserved.

\section{Introduction}

Cotton is the most important crop in terms of irrigated area and production in Central Asia, namely in Uzbekistan (FASUSDA, 2002; FAO, 2004). Excessive water is often applied to furrow irrigated cotton in Central Asia (Horst et al., 2005, 2007).
Water use is also hampered by poor water supply and distribution management that causes important problems of water wasting, waterlogging and salinity. Therefore, research has focused on improving water management at both the farm and the system scales (Pereira et al., 2005). Relative to cotton irrigation, research has shown that various

\footnotetext{
* Corresponding author. Tel.: +351 21 3653339; fax: +351 213651575.

E-mail addresses: lspereira@isa.utl.pt (L.S. Pereira), pparedes@isa.utl.pt (P. Paredes), horst_mg@icwc-aral.uz (E.D. Cholpankulov), horst_mg@icwc-aral.uz (O.P. Inchenkova), erpteodoro@yahoo.com (P.R. Teodoro), horst_mg@icwc-aral.uz (M.G. Horst). 0378-3774/\$ - see front matter (C) 2008 Elsevier B.V. All rights reserved. doi:10.1016/j.agwat.2008.10.013
} 
solutions may be adopted to improve furrow irrigation (Horst et al., 2005, 2007) and that alternative irrigation scheduling strategies are also required. With this objective, the irrigation scheduling simulation model ISAREG has been calibrated and validated for the region (Cholpankulov et al., 2008). Following this study, the current paper focuses on the search for improved cotton irrigation scheduling strategies applied to the Fergana Valley.

An appropriated irrigation scheduling plays an important role in achieving water savings, higher irrigation performances, and controlling the percolation resulting from excess water applied to irrigation (Smith et al., 1996; Pereira et al., 2002). Several studies show that cotton yields are reduced by excessive water applications (Jackson and Tilt, 1968; Grimes et al., 1969). However, most often published studies refer to impacts of water deficits on cotton growth and yields (Grimes and Yamada, 1982; Gerik et al., 1996; Pettigrew, 2004a, 2004b; Karam et al., 2006; Falkenberg et al., 2007; DeTar, 2008). The causes for water stress are well known (Bruce and Shipp, 1962; Turner et al., 1986; Pettigrew, 2004b) and relationships between irrigation methods and scheduling also allow understanding directions for improving water use and productivity (Dalton et al., 2001; Howell et al., 2004; Gibb et al., 2004; Bhattarai et al., 2006; Dagdelen et al., 2006). Several water-yield functions have been developed (Shreder et al., 1977; Doorenbos and Kassam, 1979; Ertek and Kanber, 2003; Dagdelen et al., 2006). These studies allow to clearly define that the period from flowering to yield formation is critical with respect to water deficits, and that the growth period from crop establishment to flowering is sensitive to excess water and may induce excessive vegetative growth. For the region, irrigation norms have been established to advise farmers but their application is still far from the expectations (Shreder et al., 1977; Laktaev, 1978; Domullodjanov, 1983).

Computer models are appropriate tools for developing and evaluating alternative irrigation strategies, and a large number of those models are available for computing the soil water balance and generating improved irrigation schedules. This is the case of the ISAREG model (Teixeira and Pereira, 1992; Pereira et al., 2003), which has been successfully applied to study alternative irrigation scheduling options for various crops and regions (Cancela et al., 2006; Popova and Pereira, 2008) including Central Asia where the model was successfully validated for cotton (Cholpankulov et al., 2008), and where a GIS version has been implemented (Fortes et al., 2005). The main objective of the present study is to explore ISAREG to assess alternative irrigation schedules for cotton aiming at more efficient water use and water saving.

\section{Materials and methods}

\subsection{Modeling}

The ISAREG model (Pereira et al., 2003) was selected to simulate and assess alternative irrigation schedules for cotton following its calibration and validation (Cholpankulov et al., 2008). Experimental data were used to calibrate and validate the ISAREG model for the Fergana Valley conditions. The model allows different options to define and evaluate the irrigation schedules as described in former applications (Cancela et al., 2006; Popova and Pereira, 2008). Depending on weather data availability, various time step computations can be used (daily, 10-day, monthly). The model computes the water balance for a multilayered soil and is able to consider the impacts of salinity (Pereira et al., 2007) and to estimate the groundwater contribution (GC) through a parametric function upon knowing the soil characteristics related with capillary rise, the water table depths, the crop leaf area index (LAI), and the crop evapotranspiration at various dates along the crop cycle (Liu et al., 2006).

The ISAREG model computes the crop evapotranspiration $\left(E_{\mathrm{a}}\right)$ using the methodology proposed by Allen et al. (1998). The potential crop evapotranspiration $\mathrm{ET}_{\mathrm{c}}(\mathrm{mm})$ is given by

$\mathrm{ET}_{\mathrm{C}}=\mathrm{K}_{\mathrm{C}} \mathrm{ET}_{\mathrm{o}}$

where $\mathrm{ET}_{\mathrm{o}}(\mathrm{mm})$ is the reference evapotranspiration and $\mathrm{K}_{\mathrm{C}}$ is the crop coefficient. The actual crop evapotranspiration $\left(E_{\mathrm{a}}\right)$ is lower than $\mathrm{ET}_{\mathrm{C}}$ when the soil water depletion exceeds the depletion fraction for no stress $(p)$. $\mathrm{ET}_{\mathrm{a}}$ is estimated through the soil water balance as a function of the available soil water in the root zone as described by Teixeira and Pereira (1992), and depletion is limited to the management allowed depletion (MAD). When water stress is not admitted, then $\mathrm{MAD} \leq p$ is adopted; when deficit irrigation is applied then MAD $>p$. The crop coefficients $\left(K_{c}\right)$ and depletion fractions for no stress $(p)$ were obtained from the calibration studies (Cholpankulov et al., 2008).

The model uses the methodology proposed by Stewart et al. (1977) and Doorenbos and Kassam (1979) to evaluate the water stress impacts on crop yields by computing the relative yield losses (RYL) from the relative evapotranspiration deficit through the water-yield response factor $\left(K_{\mathrm{y}}\right)$ as described by the following equation:

$\left(1-\frac{Y_{a}}{Y_{m}}\right)=K_{y}\left(1-\frac{E T_{a}}{E T_{c}}\right)$

where $\mathrm{ET}_{\mathrm{a}}$ and $\mathrm{ET}_{\mathrm{c}}$ are respectively the seasonal actual and potential crop evapotranspiration $(\mathrm{mm}), \mathrm{Y}_{\mathrm{a}}$ is the yield $\left(\mathrm{kg} \mathrm{ha}^{-1}\right.$ ) achieved when $\mathrm{ET}=\mathrm{ET}_{\mathrm{a}}$, and $\mathrm{Y}_{\mathrm{m}}$ is the potential achievable yield $\left(\mathrm{kg} \mathrm{ha}^{-1}\right)$ of a well adapted crop variety under pristine cropping conditions when $\mathrm{ET}=\mathrm{ET}_{\mathrm{c}}$. The maximum or potential crop yield $\left(\mathrm{Y}_{\mathrm{m}}\right)$ may be obtained from field observations (Popova et al., 2006) or estimated using the approach proposed by Doorenbos and Kassam (1979) when local experimental data are not available. These authors define $Y_{m}$ as the harvestable yield of a high producing crop variety, welladapted to the local growing environment, under non-limiting yield conditions in terms of water, nutrients, pests and diseases; they estimate it as a function of several climatic factors such as temperature, radiation and length of the total growing season. In this application, $Y_{m}$ was estimated with this methodology but observation data were used to support calculations. The response factor $K_{\mathrm{y}}$ was derived from literature referring to Central Asia (Shreder et al., 1977) and from furrow irrigation experimental data (Horst et al., 2007).

The parametric functions used to compute the groundwater contribution (GC) and deep percolation (DP) were 
parameterized when the model was calibrated, and are given by Cholpankulov et al. (2008).

The model input data include:

- Meteorological data concerning precipitation, $P(\mathrm{~mm})$ and reference evapotranspiration, $\mathrm{ET}_{\mathrm{o}}(\mathrm{mm})$, or weather data to compute $\mathrm{ET}_{\mathrm{o}}$ with the FAO Penman-Monteith methodology, including alternative computation methods for missing climate data (Allen et al., 1998).

- Crop data referring to dates of crop development stages, crop coefficients $\left(K_{\mathrm{c}}\right)$; root zone depths $Z_{\mathrm{r}}(\mathrm{m})$; soil water depletion fractions for no-stress $(p)$; and the seasonal water-yield response factor $\left(K_{\mathrm{y}}\right)$.

- Soil data for a multilayer soil: relative to each layer, the respective depth $d(\mathrm{~m})$; the soil water content at field capacity, $\theta_{\mathrm{FC}}\left(\mathrm{m}^{3} \mathrm{~m}^{-3}\right)$, and the wilting point, $\theta_{\mathrm{WP}}\left(\mathrm{m}^{3} \mathrm{~m}^{-3}\right)$, or the total available water, TAW $(\mathrm{mm})$; an additional file is used to parameterize the equations relative to GC and DP; the available soil water (ASW) at planting is provided by the user.

The ASW $(\mathrm{mm})$ at planting is either observed or estimated. It may be estimated by simulating the soil water balance for a bare soil condition starting at a date when ASW may be known, e.g. during the rainy season, when it may be assumed that ASW $=100 \%$ TAW. The model is then run for the weather conditions of that year until the day before planting. The computed ASW at this day is taken as the estimated ASW at planting. In this application, ASW was computed for each year of simulation, including a period of frost soil.

The model allows several options to define the irrigation depths and dates, and to adopt restrictions of the maximum water availability during a specific time period or for the crop season. Net irrigation depths (D) may be variable or fixed. In this application, fixed $D=70 \mathrm{~mm}$ are adopted following the results of the field studies by Horst et al. $(2005,2007)$ relative to improving furrow irrigation. Dates were defined through selected soil water thresholds. The alternative management strategies are the following (Table 1):

(a) full irrigation (FI), aimed at achieving the maximal yield, where $\mathrm{MAD}=p$, i.e. when the soil water threshold is $\theta_{\mathrm{p}}$, with $\theta_{\mathrm{p}}$ representing the average soil water in the root zone when depletion equals the fraction $p$; a fixed $D=70 \mathrm{~mm}$ was considered;

(b) deficit irrigation (DI) with $\mathrm{MAD}>p$ during crop growth periods when water deficits have less impacts on yields. Thresholds are $\theta_{\mathrm{MAD}}=0.75 \theta_{\mathrm{p}}$ between crop establishment and flowering and between yield formation and harvesting, and $\theta_{\mathrm{MAD}}=\theta_{\mathrm{p}}$ for the initial and mid season periods, the latter between flowering and yield formation. Fixed $\mathrm{D}=70 \mathrm{~mm}$ is adopted. Two types of alternatives are considered for simulation: one with a number of irrigations conditioned by minimizing RYL (DI-RYL), the other where the number of irrigations is decreased by 1,2 or 3 (DI-1, 2 and 3) as defined in Table 1.

For all irrigation schedules, the date of the last irrigation is at least 20 days before harvesting because cotton lint quality is affected when its moisture content at harvest is higher than 8\% (Barker, 1982, 1996; Barker and Laird, 1993).

Two different approaches were used for the present study: the first one uses the daily meteorological data (2001-2003) and the second uses a 10-day time series for the period 1970-2003. The crop characteristics used for the simulations are those observed in 2003.

The modeling results are assessed by comparing the predicted water productivity, WP $\left(\mathrm{kg} \mathrm{m}^{-3}\right.$ or $\left.\mathrm{kg} \mathrm{mm}^{-1}\right)$, and the economic water productivity, EWP $\left(€ \mathrm{~m}^{-3}\right)$. WP is defined (Pereira, 2007) by the ratio between the actual yield, $Y_{a}(\mathrm{~kg})$ and the total water use, TWU $\left(\mathrm{m}^{3}\right)$ :

$\mathrm{WP}=\frac{\mathrm{Y}_{\mathrm{a}}}{\mathrm{TWU}}$

or, indicating the components of TWU,

$\mathrm{WP}=\frac{\mathrm{Ya}_{\mathrm{a}}}{\mathrm{P}+\mathrm{GC}+\Delta \mathrm{SW}+\mathrm{I}}$

where $P$ is the season precipitation $(\mathrm{mm}), \mathrm{GC}$ is the season groundwater contribution $(\mathrm{mm}), \Delta \mathrm{SW}$ is the difference in soil water content between planting and harvesting $(\mathrm{mm})$, and $I$ is the seasonal gross irrigation depth $(\mathrm{mm})$. In this formulation WP is expressed in $\mathrm{kg} \mathrm{mm}^{-1}$ and the yield refers to the unit surface. I is obtained from $D$ by considering the application efficiency $E_{\mathrm{a}}$ as observed by Horst et al. (2005, 2007). EWP is defined when replacing the numerator of Eqs. (3) and (4) by the monetary value of the achieved yield, Value $\left(\mathrm{Y}_{\mathrm{a}}\right)(€)$, thus:

$\mathrm{EWP}=\frac{\text { Value }\left(\mathrm{Y}_{\mathrm{a}}\right)}{\mathrm{TWU}}$

\subsection{Experimental site and data}

The experimental farm "Azizbek-1" is located in the Fergana Valley near the Fergana town, Uzbekistan. The meteorological station $\left(40.77^{\circ} \mathrm{N}, 71.09^{\circ} \mathrm{E}, 439 \mathrm{~m}\right.$ elevation) is located in this town. The respective average monthly climate data are presented in Table 2. The Valley is bordered by the Fergana ridge in the East, the Alai and Turkestan ridges in the South and the Kurama and Chatkal ridges in the Northwest and the
Table 1 - Summary of the irrigation scheduling strategies.

\begin{tabular}{|c|c|c|c|c|}
\hline Symbol & Irrigation strategy & MAD & $D$ & Number of irrigations \\
\hline FI & Full irrigation & $\mathrm{MAD}=p$ & $D=70 \mathrm{~mm}$ & Not restricted \\
\hline DI-RYL & Deficit irrigation, with minimal RYL & MAD $<p$ & $D=70 \mathrm{~mm}$ & Not restricted \\
\hline DI-1 & Deficit irrigation & $\mathrm{MAD}<p$ & $\mathrm{D}=70 \mathrm{~mm}$ & Less 1 than FI \\
\hline DI-2 & Deficit irrigation & MAD $<p$ & $\mathrm{D}=70 \mathrm{~mm}$ & Less 2 than FI \\
\hline DI-3 & Deficit irrigation & MAD $<p$ & $\mathrm{D}=70 \mathrm{~mm}$ & Less 3 than FI \\
\hline
\end{tabular}


Table 2 - Average climatic data of the Fergana meteorological station (1970-2003).

January February March April May June July August September October November December

\begin{tabular}{|c|c|c|c|c|c|c|c|c|c|c|c|c|}
\hline $\begin{array}{c}\text { Temperature } \\
\max .\left[{ }^{\circ} \mathrm{C}\right]\end{array}$ & 4.0 & 6.5 & 13.7 & 22.2 & 27.7 & 32.9 & 34.6 & 33.2 & 28.4 & 21.2 & 13.1 & 6.2 \\
\hline $\begin{array}{c}\text { Temperature } \\
\min .\left[{ }^{\circ} \mathrm{C}\right]\end{array}$ & -3.7 & -1.7 & 4.0 & 10.6 & 14.5 & 18.3 & 20.1 & 18.2 & 13.3 & 7.9 & 2.8 & -1.5 \\
\hline $\begin{array}{l}\text { Relative } \\
\text { humidity [\%] }\end{array}$ & 81 & 77 & 68 & 60 & 54 & 46 & 47 & 51 & 55 & 65 & 74 & 81 \\
\hline $\begin{array}{l}\text { Wind speed } \\
{\left[\mathrm{m} \mathrm{s}^{-1}\right]}\end{array}$ & 1.0 & 1.2 & 1.4 & 1.6 & 1.7 & 1.7 & 1.5 & 1.4 & 1.2 & 1.1 & 1.1 & 1.0 \\
\hline $\begin{array}{l}\text { Sunshine } \\
\text { duration [h] }\end{array}$ & 90 & 120 & 150 & 210 & 270 & 330 & 330 & 330 & 270 & 210 & 150 & 90 \\
\hline $\mathrm{ET}_{\mathrm{o}}\left[\mathrm{mm} \mathrm{d}^{-1}\right]$ & 1.4 & 1.7 & 2.5 & 3.7 & 4.5 & 5.5 & 5.7 & 5.4 & 4.7 & 3.4 & 2.2 & 1.5 \\
\hline $\begin{array}{l}\text { Precipitation } \\
{[\mathrm{mm}]}\end{array}$ & 18.0 & 21.4 & 24.3 & 22.1 & 19.9 & 9.4 & 4.2 & 2.7 & 5.9 & 17.6 & 17.4 & 19.9 \\
\hline
\end{tabular}

Table 3 - Dates of the cotton crop growth stages, and calibrated crop coefficients $\left(\mathrm{K}_{\mathrm{c}}\right)$ and depletion fractions for no stress (p), Fergana Valley.

\begin{tabular}{llll} 
Parameters & \multicolumn{1}{c}{ Initial } & Development & Mid season season \\
\hline $\begin{array}{l}\text { Period length (dates) } \\
2001 \text { (calibration) }\end{array}$ & $13 / 04-17 / 05$ & $18 / 05-17 / 07$ & $18 / 07-31 / 08$ \\
2003 (validation) & $06 / 04-20 / 05$ & $21 / 05-19 / 07$ & $20 / 07-01 / 09$ \\
Crop coefficients, $K_{\mathrm{c}}$ & 0.30 & $0.30-1.20$ & 0.6 \\
Depletion fraction, $p$ & 0.6 & 0.6 & 0.6 \\
\hline
\end{tabular}

North. The Fergana Valley is drained by the SyrDarya River and numerous mountain streams that are fed by the glaciers in the mountains. The experimental area is located south of the SyrDarya River.

The main soils in the experimental site are loamy and clayloam. The unsaturated soil hydraulic properties were determined from an appropriate survey and using laboratory methods for the full range of soil water tension. Weighed average values referring to the soil depth considered for the simulations (1.0 m) are (Cholpankulov et al., 2008):

- Field capacity, $\theta_{\mathrm{FC}}=0.31 \mathrm{~m}^{3} \mathrm{~m}^{-3}$;

- Wilting point, $\theta_{\mathrm{WP}}=0.16 \mathrm{~m}^{3} \mathrm{~m}^{-3}$;

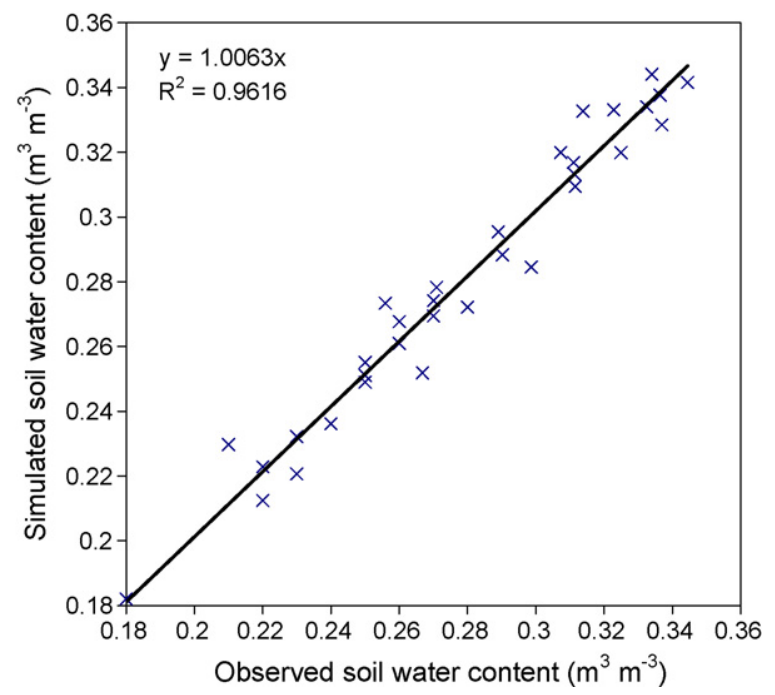

Fig. 1 - Comparison between observed and simulated soil water content using the data for 2001 and 2003.
- Total available water, $\mathrm{TAW}=148 \mathrm{~mm} \mathrm{~m}^{-1}$.

On the experimental site, during the period 2001-2003, the water-table depths varied between 1.10 and $2.60 \mathrm{~m}$. Related observations were used for the calibration and validation of the model; the parameters used to compute GC and DP are given by Cholpankulov et al. (2008).

The crop coefficients $\left(K_{c}\right)$ and the depletion fractions for no stress $(p)$ derived from the calibration and validation studies are presented in Table 3 (Cholpankulov et al., 2008). The values for both $K_{\mathrm{c}}$ and $p$ are in the range of those recommended by Allen et al. (1998). However, the $K_{\mathrm{c}}$ end, values are higher due to a late irrigation. The comparison between the simulated and observed soil water content using the calibrated crop parameters (Table 3) is shown in Fig. 1 for the experiments developed in 2001 and 2003. Results show a good agreement between observed and computed soil water content.

The yield response factor $K_{\mathrm{y}}=1.11$ was selected from cotton experiments in Fergana (Horst et al., 2007). This value is higher than that calculated from the curve proposed by Shreder et al. (1977) for the region, and that proposed by Doorenbos and Kassam (1979) due to adopting a new and more productive variety (Gossipium hirsutum var. upland C-6524), which is also more sensitive to water stress. Similar high values for $K_{\mathrm{y}}$ are found in literature (Yazar et al., 2002; Dagdelen et al., 2006; DeTar, 2008).

\section{Results}

\subsection{Net irrigation requirements}

Net irrigation requirements, NIR ( $\mathrm{mm})$, were computed for the weather time series 1970-2003 aiming at identifying the years 


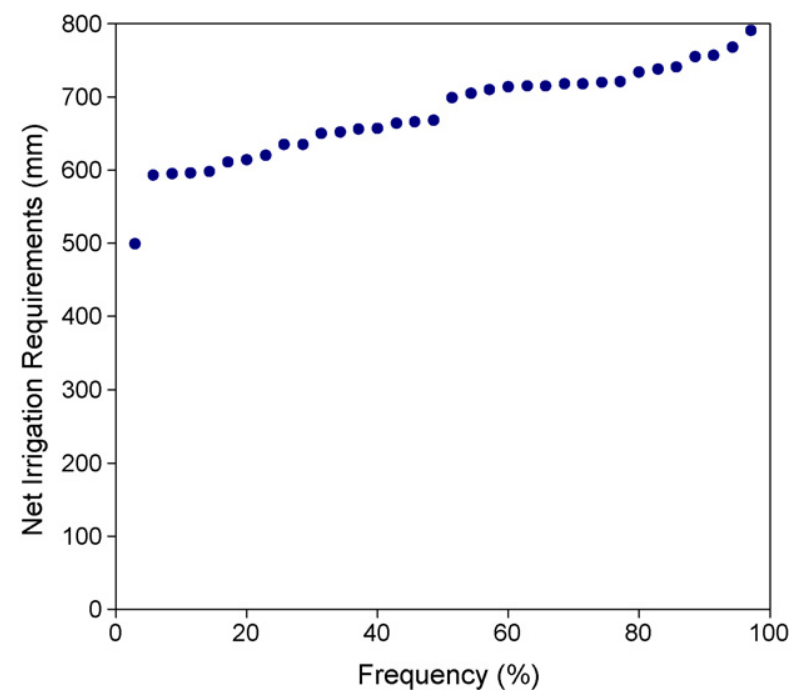

Fig. 2 - Frequency distribution of the net irrigation requirements (NIR) for the cotton crop, Fergana Valley (1970-2003).

representing average, high and very high demand, which correspond respectively to the probabilities of 50,80 and $95 \%$ for non-exceedance. Simulations were performed for all years in the series using the crop parameters in Table 3, crop stages dates for 2003, and ASW at planting estimated through a specific simulation as referred before.

The NIR for the complete time series are given in Fig. 2. Assuming a normal distribution for the resulting NIR time series, the years corresponding to the probabilities of 50,80 and $95 \%$ for non-exceedance were then identified, respectively 1973, 1971 and 1984. It could be observed that the years when daily data are available are of low demand: the years 2001 and 2002 have non-exceedance frequencies lower than $30 \%$, and the year 2003 is the most humid year of the data time series.

Results in Fig. 2 show that NIR for cotton vary in a relatively narrow range (791-593 $\mathrm{mm}$ ) except for 2003 when NIR is much lower $(499 \mathrm{~mm})$. Data in Fig. 3 show that

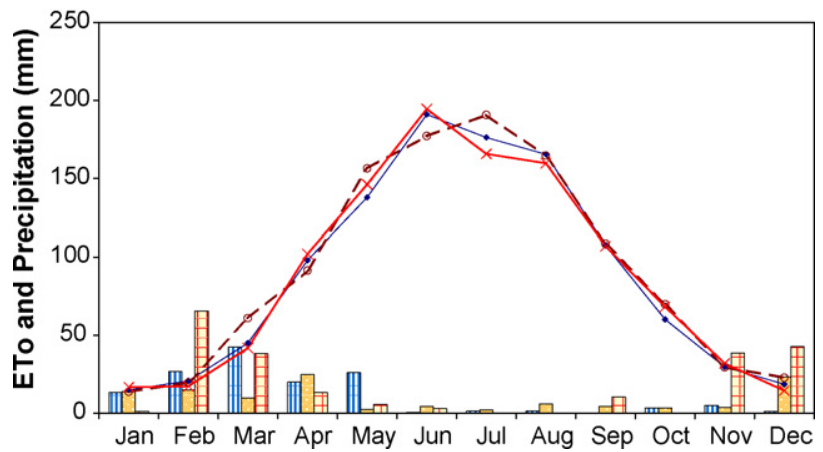

Fig. 3 - Mean monthly precipitation for average (॥), high ( ) and very high ( $)$ climatic demand, and mean monthly ET for the average $(\diamond)$, high $(\bigcirc)$ and very high $(x)$ climatic demand.

differences in climatic conditions for the selected three levels of demand are mainly due to precipitation, and that $\mathrm{ET}_{\mathrm{o}}$ has low variability. Data in this figure show that dry conditions prevail during the cotton crop season.

The main components of the water balance when computing NIR (ASW at planting, the season rainfall, the season crop evapotranspiration, and the season net irrigation requirements) are given in Tables 4 and 5 respectively for the period 2001-2003, and for the average, high and very high climatic demand conditions.

\subsection{Current irrigation schedules and related improvements}

The cotton irrigation schedules currently used in the Fergana Valley were simulated with daily weather data to assess the present irrigation conditions (Table 6 and Fig. 4).

Results (Table 6 and Fig. 4) show that farmers tend to anticipate water applications and adopt very high irrigation depths (ranging from 86 to $174 \mathrm{~mm}$ ), which lead to relatively high deep percolation and to poor use of rainfall. This strategy corresponds to adopt a depletion fraction for no stress $p=0.45$, which is much smaller than the optimal one, $p=0.6$ (Horst

Table 4 - Available soil water at planting, seasonal rainfall, crop evapotranspiration, and net irrigation requirements of cotton for the period of field experiments (2001-2003), Fergana.

\begin{tabular}{ccccc} 
Year & ASW at planting $(\mathrm{mm})$ & Season rainfall $(\mathrm{mm})$ & Season ET $_{\mathrm{c}}(\mathrm{mm})$ & Season NIR $(\mathrm{mm})$ \\
\hline 2001 & 140 & 45 & 695 & 635 \\
2002 & 120 & 84 & 693 & 596 \\
2003 & 126 & 172 & 683 & 499 \\
\hline
\end{tabular}

Table 5 - Available soil water at planting, seasonal rainfall, crop evapotranspiration, and net irrigation requirements of cotton for the selected demand conditions during 1970-2003, Fergana.

\begin{tabular}{lccc} 
Demand condition & ASW at planting $(\mathrm{mm})$ & Season rainfall $(\mathrm{mm})$ & Season ET $(\mathrm{mm})$ \\
\hline Average & 121 & 52 & 768 \\
High & 118 & 40 & 799 \\
Very high & 104 & 31 & 734 \\
\hline
\end{tabular}


Table 6 - Simulation of cotton irrigation scheduling, 2001 and 2003, using actual irrigation dates and depths.

\begin{tabular}{|c|c|c|c|}
\hline \multicolumn{2}{|l|}{2001} & \multicolumn{2}{|c|}{2003} \\
\hline Date & Depth (mm) & Date & Depth (mm) \\
\hline 8 April $^{\mathrm{a}}$ & 143 & $14 \mathrm{March}^{\mathrm{a}}$ & 171 \\
\hline 2 June & 127 & 15 June & 125 \\
\hline 25 June & 174 & 6 July & 103 \\
\hline 11 July & 123 & 23 July & 123 \\
\hline 25 July & 111 & 8 August & 114 \\
\hline \multirow[t]{2}{*}{7 August } & 86 & 24 August & 91 \\
\hline & & 10 September & 93 \\
\hline \multirow{2}{*}{\multicolumn{2}{|c|}{ Water balance components }} & \multicolumn{2}{|r|}{ Depth } \\
\hline & & 2001 & 2003 \\
\hline \multicolumn{2}{|c|}{ Season irrigation $(\mathrm{mm})$} & 764 & 820 \\
\hline \multicolumn{2}{|c|}{ ASW at planting (mm) } & 140 & 126 \\
\hline \multicolumn{2}{|c|}{ ASW at harvesting $(\mathrm{mm})$} & 36 & 103 \\
\hline \multicolumn{2}{|c|}{ Precipitation $(\mathrm{mm})$} & 45 & 172 \\
\hline \multicolumn{2}{|c|}{ Non-used precipitation (mm) } & - & 50 \\
\hline \multicolumn{2}{|c|}{ Groundwater contribution (mm) } & 94 & 29 \\
\hline \multicolumn{2}{|c|}{ Percolation (mm) } & 230 & 140 \\
\hline \multicolumn{2}{|c|}{$\mathrm{ET}_{\mathrm{a}}(\mathrm{mm})$} & 635 & 683 \\
\hline \multicolumn{2}{|l|}{$\mathrm{ET}_{\mathrm{c}}(\mathrm{mm})$} & 695 & 683 \\
\hline
\end{tabular}

et al., 2005, 2007). Percolation ranges from 140 to $230 \mathrm{~mm}$ and largely exceeds the leaching requirements $(5 \%$ of the irrigation depths). A slight water stress $\left(\mathrm{ET}_{\mathrm{a}}<\mathrm{ET}_{\mathrm{c}}\right)$ is observed because water was not always available in due time. Results indicate that groundwater contribution is small, which relates to the fact that deep drainage is effectively controlling the water table (Dukhovny et al., 2005).

Results show that the current irrigation schedules are not appropriate to cope with the water scarcity conditions prevailing in the region, marked by both aridity and desertification, thus requiring a more efficient use of the irrigation water. This implies that irrigation dates should be better adjusted and irrigation depths controlled to decrease both deep percolation and runoff as demonstrated through studies for improving furrow irrigation (Horst et al., 2007). In addition, water productivity must be improved; nevertheless, when saving irrigation water only a limited yield decrease is acceptable because farmers' incomes are quite small in the region.

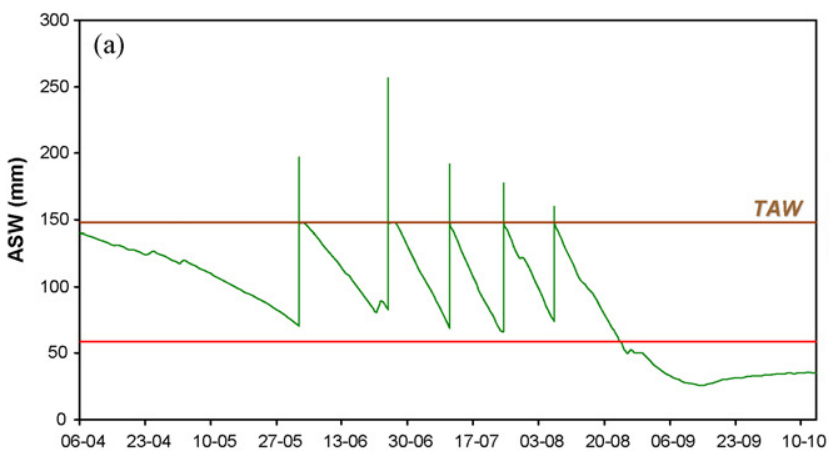

Table 7 - Water balance relative to the full irrigation strategy (FI), 2001-2003.

Irrigation dates

\begin{tabular}{llc}
\hline 2001 & \multicolumn{1}{c}{2002} & 2003 \\
\hline $06-06$ & Pre-planting & \\
$28-06$ & $19-06$ & $28-06$ \\
$11-07$ & $05-07$ & $11-07$ \\
$22-07$ & $17-07$ & $22-07$ \\
$05-08$ & $28-07$ & $02-08$ \\
$19-08$ & $09-08$ & $16-08$ \\
$05-09$ & $22-08$ & $30-08$ \\
& $12-09$ & $19-09$ \\
\end{tabular}

\begin{tabular}{lrrr}
\hline \multirow{2}{*}{ Water balance components } & \multicolumn{3}{c}{ Depth } \\
\cline { 2 - 4 } & 2001 & 2002 & 2003 \\
\hline Season irrigation (mm) & 490 & 560 & 490 \\
ASW at planting (mm) & 140 & 120 & 126 \\
ASW at harvesting (mm) & 53 & 63 & 106 \\
Precipitation (mm) & 45 & 84 & 172 \\
Non-used precipitation (mm) & - & - & 50 \\
Groundwater contribution (mm) & 72 & 63 & 51 \\
ET $_{\text {a }}(\mathrm{mm})$ & 697 & 693 & 683 \\
ET $_{\mathrm{c}}(\mathrm{mm})$ & 697 & 693 & 683 \\
\hline
\end{tabular}

${ }^{a}$ Pre-planting irrigation $=70 \mathrm{~mm}$.

\subsubsection{Full irrigation}

For the period 2001-2003 conditions, improved irrigation schedules were designed for water saving and percolation control and simultaneously maximizing crop yields (Table 7). The irrigation depths used were $D=70 \mathrm{~mm}$, thus in agreement with those defined for improving furrow irrigation (Horst et al., 2005, 2007).

The season rainfall varied from 45 to $172 \mathrm{~mm}$, and season crop ET from 683 to $697 \mathrm{~mm}$. The ASW at harvesting is adequate and indicates that the crop uses well the soil water when irrigation is ceased 20 days before harvesting. Results also show $\mathrm{ET}_{\mathrm{a}}=\mathrm{ET}_{\mathrm{c}}$, thus indicating that water stress is not induced.

Comparing FI with the actual irrigation schedules in Table 6, because the irrigation depths per event are smaller than those currently practiced, the number of irrigation events is higher but the total irrigation applied is smaller. The groundwater contribution varies between 9 and $12 \%$ of the total crop water requirements and is similar to that in Table 6.

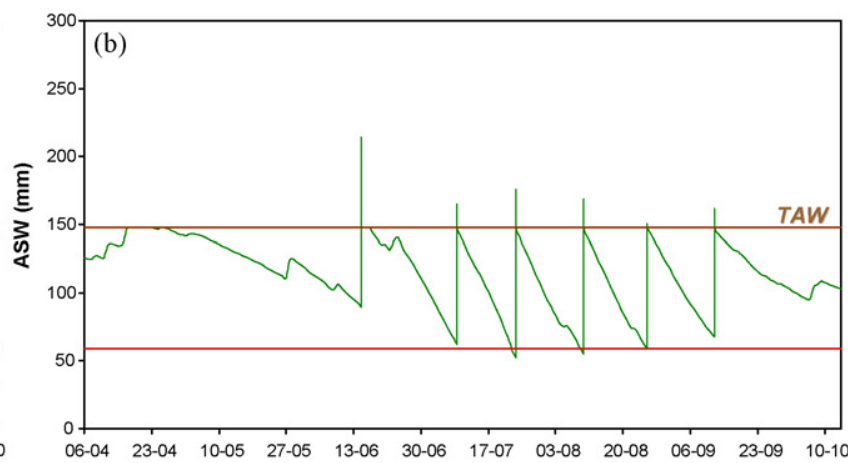

Fig. 4 - Seasonal variation of available soil water $(\mathrm{mm})$ for the current cotton irrigation schedules in: (a) 2001 ; and (b) 2003. 
Table 8 - Simulated deficit irrigation schedules for cotton, 2001-2003.

\begin{tabular}{|c|c|c|c|c|c|c|c|}
\hline Year & $\begin{array}{l}\text { Irrigation } \\
\text { strategy }\end{array}$ & $\begin{array}{c}\text { Season } \\
\text { irrigation }(\mathrm{mm})\end{array}$ & $\begin{array}{c}\text { ASW at } \\
\text { planting }(\mathrm{mm})\end{array}$ & $\begin{array}{c}\text { ASW at } \\
\text { harvesting }(\mathrm{mm})\end{array}$ & $\begin{array}{c}\text { Groundwater } \\
\text { contribution }(\mathrm{mm})\end{array}$ & $\begin{array}{l}\mathrm{ET}_{\mathrm{a}} \\
(\mathrm{mm})\end{array}$ & $\begin{array}{l}\text { RYL } \\
(\%)\end{array}$ \\
\hline \multirow[t]{4}{*}{2001} & DI-RYL & 490 & \multirow[t]{4}{*}{140} & 57 & 74 & 693 & 1 \\
\hline & DI-1 & 420 & & 37 & 96 & 664 & 5 \\
\hline & DI-2 & 350 & & 36 & 116 & 616 & 13 \\
\hline & DI-3 & 280 & & 35 & 132 & 562 & 21 \\
\hline \multirow[t]{4}{*}{2002} & DI-RYL & $560^{a}$ & \multirow[t]{4}{*}{120} & 76 & 69 & 686 & 1 \\
\hline & DI-1 & $490^{\mathrm{a}}$ & & 39 & 88 & 672 & 3 \\
\hline & DI-2 & $420^{a}$ & & 36 & 110 & 620 & 11 \\
\hline & DI-3 & $350^{\mathrm{a}}$ & & 36 & 126 & 573 & 19 \\
\hline \multirow[t]{4}{*}{2003} & DI-RYL & 420 & \multirow[t]{4}{*}{126} & 62 & 73 & 678 & 1 \\
\hline & DI-1 & 350 & & 52 & 93 & 638 & 7 \\
\hline & DI-2 & 280 & & 50 & 108 & 586 & 16 \\
\hline & DI-3 & 210 & & 49 & 121 & 530 & 25 \\
\hline
\end{tabular}

a Includes a pre-planting irrigation of $70 \mathrm{~mm}$.

The ASW at harvesting is smaller than those simulated for the current schedules (Table 6), thus indicating better use of soil water and rainfall.

Results demonstrate that when appropriate irrigation depths and timings are selected the seasonal irrigation could be reduced and deep percolation could be controlled, so avoiding that the water table rises with consequent impacts on soil salinization.

\subsubsection{Deficit irrigation}

Results of the simulation of the deficit irrigation schedules defined in Table 1 are summarized in Table 8. Results for the DI-RYL strategy show that even though the total irrigation applied is smaller than that required to fully satisfy the irrigation requirements, the relative yield losses are minimized ( $\mathrm{RYL} \approx 1 \%$ ). The $\mathrm{DI}$ strategies lead to higher groundwater contribution than full irrigation, which become 10-31\% of the total crop water requirements. They also lead to smaller ASW at harvesting, thus to a better use of soil water and precipitation. However, decreasing the number of irrigations to save water, leads to a larger RYL: $3-7 \%$ for DI-1, $11-16 \%$ for
DI-2, and $19-25 \%$ for DI-3. Such a high water saving resulting from cutting 2 or 3 irrigations is economically questionable considering that farmers in the region have a low income.

For better comparing the FI and DI strategies, soil water simulations along the crop season are presented in Fig. 5. They show that precipitation occurring during the spring time for both 2001 and 2003 avoids stress during the early crop stages and that water deficits impact only the later stage of the crop, mainly when DI results from cutting an irrigation event (Fig. 5c). Further cutting of irrigation events lead to water stress during the mid season stage, thus highly impacting yields.

\subsubsection{Water productivity and water saving}

The water productivity and economic water productivity [Eqs. (3)-(5)] are presented in Table 9 for all the improved irrigation schedules. The simulated yield results are in accordance with the ones measured in field experiments (Horst et al., 2007). However, WP results are slightly higher than those obtained at field level because larger total water depths were applied in the field studies.

Table 9 - Simulated cotton gross irrigation, total water use (TWU), yield, water productivity, yield value and economic water productivity for the improved irrigation schedules, 2001-2003.

\begin{tabular}{|c|c|c|c|c|c|c|c|}
\hline Year & $\begin{array}{l}\text { Irrigation } \\
\text { strategy }\end{array}$ & $\begin{array}{c}\text { Gross irrigation } \\
(\mathrm{mm})\end{array}$ & $\begin{array}{l}\text { TWU } \\
(\mathrm{mm})\end{array}$ & $\begin{array}{c}\text { Yield } \\
\left(\mathrm{kg} \mathrm{ha}^{-1}\right)\end{array}$ & $\begin{array}{c}\text { WP } \\
\left(\mathrm{kg} \mathrm{m}^{-3}\right)\end{array}$ & $\begin{array}{c}\text { Yield } \\
\text { value }\left(€ \mathrm{ha}^{-1}\right)\end{array}$ & $\begin{array}{c}\text { EWP } \\
\left(€ \mathrm{~m}^{-3}\right)\end{array}$ \\
\hline \multirow[t]{5}{*}{2001} & FI & 817 & 1021 & 3722 & 0.365 & 1720 & 0.168 \\
\hline & DI-RYL & 815 & 1017 & 3699 & 0.363 & 1709 & 0.168 \\
\hline & DI-1 & 700 & 944 & 3527 & 0.374 & 1629 & 0.173 \\
\hline & DI-2 & 583 & 849 & 3242 & 0.382 & 1498 & 0.176 \\
\hline & DI-3 & 467 & 749 & 2922 & 0.390 & 1350 & 0.180 \\
\hline \multirow[t]{5}{*}{2002} & FI & 933 & 1138 & 3665 & 0.322 & 1693 & 0.149 \\
\hline & DI-RYL & 930 & 1134 & 3624 & 0.320 & 1674 & 0.148 \\
\hline & DI-1 & 817 & 1070 & 3542 & 0.331 & 1636 & 0.153 \\
\hline & DI-2 & 700 & 978 & 3236 & 0.331 & 1495 & 0.153 \\
\hline & DI-3 & 583 & 878 & 2960 & 0.337 & 1367 & 0.156 \\
\hline \multirow[t]{5}{*}{2003} & FI & 817 & 1060 & 3625 & 0.342 & 1674 & 0.158 \\
\hline & DI-RYL & 700 & 1009 & 3595 & 0.356 & 1661 & 0.165 \\
\hline & DI-1 & 583 & 922 & 3360 & 0.364 & 1552 & 0.168 \\
\hline & DI-2 & 467 & 822 & 3053 & 0.371 & 1410 & 0.172 \\
\hline & DI-3 & 350 & 720 & 2723 & 0.378 & 1258 & 0.175 \\
\hline
\end{tabular}



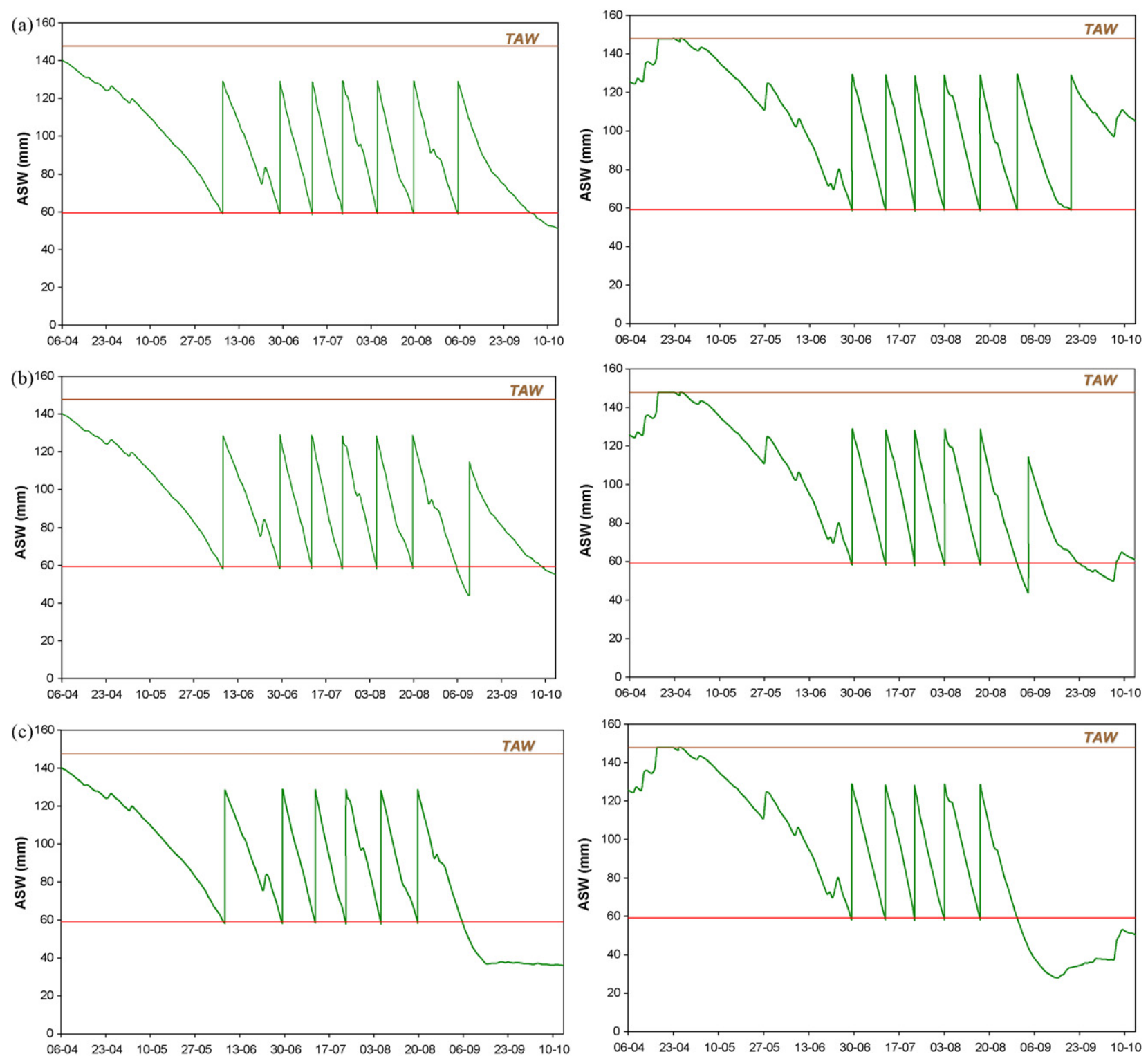

Fig. 5 - Seasonal variation of available soil water ( $\mathrm{mm}$ ) for the cotton irrigation schedules: (a) FI, (b) DI-RYL, (c) DI-1; on the left for the 2001 conditions and on the right for 2003.

The WP is higher for the DI strategies since they correspond to a reduction in gross irrigation water use (Table 9). However, the resulting increase is small because yields decrease with water deficits. The EWP also slightly increases with deficit irrigation; however the yield value highly decreases when DI-2 and DI-3 are considered (approximately $220 € \mathrm{ha}^{-1}$ for DI-2 and up to $420 € \mathrm{ha}^{-1}$ in case of DI-3), thus making it questionable that such DI strategies could be applicable to small farms.

Comparing the FI scheduling strategy with the DI-RYL, results in Table 9 show that for the years 2001 and 2002 there is no water saving and the RYL are minimal ( $\leq 1 \%)$. Differently, for 2003 DI-RYL has one irrigation event less than FI, corresponding to a saving of $117 \mathrm{~mm}$ with $\mathrm{RYL} \approx 1 \%$. When considering the DI-1 strategy, the water saving is $117 \mathrm{~mm}$ for 2001 and 2002, and $233 \mathrm{~mm}$ in 2003, causing a small RYL
( $\mathrm{RYL}<7 \%$ relative to FI and $<6.5 \%$ relative to DI-RYL). This is possible because there is then a better use of soil water and groundwater contribution, which leads to a small difference in TWU (approximately 7\%). However, for DI-2 the gross irrigation savings are $117 \mathrm{~mm}$ larger but leading to a larger RYL, now of $11-16 \%$. Yield impacts are not very high because GC is high (Table 8), thus providing for a TWU decrease of only $17 \%$ in 2001 and $22 \%$ in 2003. Larger irrigation water savings are possible with DI-3 but then the yield impacts are higher $(19 \%<$ RYL $<25 \%)$ since TWU is then much smaller (Table 9).

The results indicate that water saving strategies imply improved irrigation systems that allow adopting the preferred irrigation water depths and creating conditions to make a better use of soil water and groundwater contribution. It includes delaying the first irrigation to favour crop roots development and better exploring the soil root zone. 
Table 10 - Full irrigation strategy (FI) for selected climatic demand scenarios.

Irrigation dates

\begin{tabular}{|c|c|c|c|}
\hline Average demand & High demand & \multicolumn{2}{|c|}{ Very high demand } \\
\hline $14-06$ & 05-06 & \multicolumn{2}{|r|}{$25-05$} \\
\hline $30-06$ & $25-06$ & \multicolumn{2}{|r|}{$18-06$} \\
\hline $14-07$ & $09-07$ & \multicolumn{2}{|r|}{$03-07$} \\
\hline $25-07$ & $20-07$ & \multicolumn{2}{|r|}{$14-07$} \\
\hline $05-08$ & $31-07$ & \multicolumn{2}{|r|}{$24-07$} \\
\hline $17-08$ & $11-08$ & \multicolumn{2}{|r|}{$03-08$} \\
\hline $28-08$ & $24-08$ & \multicolumn{2}{|r|}{$13-08$} \\
\hline \multirow[t]{3}{*}{ 10-09 } & 03-09 & \multicolumn{2}{|r|}{ 24-08 } \\
\hline & $18-09$ & \multirow{2}{*}{\multicolumn{2}{|c|}{$\begin{array}{l}06-09 \\
22-09\end{array}$}} \\
\hline & & & \\
\hline $\begin{array}{l}\text { Water balance } \\
\text { components }\end{array}$ & $\begin{array}{l}\text { Average } \\
\text { demand }\end{array}$ & $\begin{array}{c}\text { High } \\
\text { demand }\end{array}$ & $\begin{array}{l}\text { Very high } \\
\text { demand }\end{array}$ \\
\hline ASW at planting $(\mathrm{mm})$ & 121 & 118 & 104 \\
\hline ASW at harvesting ( $\mathrm{mm})$ & 46 & 53 & 72 \\
\hline Precipitation (mm) & 52 & 40 & 31 \\
\hline $\begin{array}{l}\text { Groundwater } \\
\text { contribution }(\mathrm{mm})\end{array}$ & 74 & 57 & 56 \\
\hline $\mathrm{ET}_{\mathrm{a}}(\mathrm{mm})$ & 762 & 792 & 818 \\
\hline $\mathrm{ET}_{\mathrm{c}}(\mathrm{mm})$ & 768 & 792 & 818 \\
\hline
\end{tabular}

\subsection{Improved irrigation schedules for selected climatic demand scenarios}

\subsubsection{Irrigation scheduling to maximize yields}

The irrigation schedules aimed at maximizing the crop yields (FI strategy), thus not allowing water stress $\left(\mathrm{ET}_{\mathrm{a}}=\mathrm{ET}_{\mathrm{c}}\right)$, were analyzed for the average, high and very high climatic demand years, which correspond to the average, dry and very dry years identified above (respectively 1973, 1971 and 1984). Results for this irrigation strategy are presented in Table 10. The components of the water balance are similar to those in Table 7 except for the precipitation and irrigation amounts, which vary with the climatic conditions.

\subsubsection{Deficit irrigation schedules}

The results of the water balance simulation for the DI-RYL strategy are presented in Table 11 . Comparing with the FI strategy (Table 10) it can be noted that one irrigation less is required for the dry and very dry years.
Table 11 - Water balance of the mild deficit irrigation strategy DI-RYL for selected climatic demand scenarios.

Irrigation dates

\begin{tabular}{|c|c|c|c|}
\hline Average demand & High demand & \multicolumn{2}{|c|}{ Very high demand } \\
\hline $30-06$ & $25-06$ & \multicolumn{2}{|r|}{$19-06$} \\
\hline $15-07$ & $09-07$ & \multicolumn{2}{|r|}{ 03-07 } \\
\hline $26-07$ & $21-07$ & \multicolumn{2}{|r|}{$14-07$} \\
\hline $06-08$ & $31-07$ & \multicolumn{2}{|r|}{ 24-07 } \\
\hline $17-08$ & $11-08$ & \multicolumn{2}{|r|}{$03-08$} \\
\hline 01-09 & $27-08$ & \multicolumn{2}{|r|}{$13-08$} \\
\hline $15-09$ & 07-09 & \multicolumn{2}{|r|}{$28-08$} \\
\hline & & \multicolumn{2}{|r|}{$12-09$} \\
\hline $\begin{array}{l}\text { Water balance } \\
\text { components }\end{array}$ & $\begin{array}{l}\text { Average } \\
\text { demand }\end{array}$ & $\begin{array}{l}\text { High } \\
\text { demand }\end{array}$ & $\begin{array}{l}\text { Very high } \\
\text { demand }\end{array}$ \\
\hline Season irrigation (mm) & 560 & 560 & 630 \\
\hline ASW at planting $(\mathrm{mm})$ & 121 & 118 & 104 \\
\hline ASW at harvesting $(\mathrm{mm})$ & 50 & 32 & 42 \\
\hline Precipitation (mm) & 52 & 40 & 31 \\
\hline $\begin{array}{l}\text { Groundwater } \\
\text { contribution }(\mathrm{mm})\end{array}$ & 77 & 75 & 78 \\
\hline $\mathrm{ET}_{\mathrm{a}}(\mathrm{mm})$ & 760 & 762 & 800 \\
\hline $\mathrm{ET}_{\mathrm{c}}(\mathrm{mm})$ & 768 & 792 & 818 \\
\hline RYL (\%) & 1 & 4 & 2 \\
\hline
\end{tabular}

This causes a small impact on yields, with 4 and 2\% RYL for these years.

Results of other DI strategies are summarized in Table 12. They show that adopting the DI-1 strategy leads to one irrigation event less than DI-RYL, thus saving about $12 \%$ of irrigation water with relatively small RYL (7 and 11\%). As analyzed above, these RYL values are small because there is a good use of the available soil water and the groundwater contribution is relatively high (Table 12). DI-2 and DI-3 show less irrigation water use $25-33 \%$ for the DI-2 and $38-44 \%$ for the DI-3 strategy) and with relatively high impacts on yields (RYL for the DI-2 is 15-19\% and 23-26\% for the DI-3 strategy). The use of the available soil water is similar to that of DI-1 but GC increases when less irrigation is applied. As analyzed in the previous section, those yield impacts may be economically not justified when small farms are considered.

To illustrate the role of groundwater contribution, Fig. 6 shows both the available soil water and the groundwater contribution variation along the crop cycle for the very high

Table 12 - Results for deficit irrigation strategies DI-1, DI-2 and DI-3.

\begin{tabular}{|c|c|c|c|c|c|c|c|}
\hline Demand condition & $\begin{array}{c}\text { Irrigation } \\
\text { strategy }\end{array}$ & $\begin{array}{c}\text { Season } \\
\text { irrigation }(\mathrm{mm})\end{array}$ & $\begin{array}{c}\text { ASW at } \\
\text { planting }(\mathrm{mm})\end{array}$ & $\begin{array}{c}\text { ASW at } \\
\text { harvesting }(\mathrm{mm})\end{array}$ & $\begin{array}{c}\text { Groundwater } \\
\text { contribution }(\mathrm{mm})\end{array}$ & $\begin{array}{l}\mathrm{ET}_{\mathrm{a}} \\
(\mathrm{mm})\end{array}$ & $\begin{array}{l}\text { RYL } \\
(\%)\end{array}$ \\
\hline \multirow[t]{3}{*}{ Average } & DI-1 & 490 & \multirow[t]{3}{*}{121} & 37 & 93 & 720 & 7 \\
\hline & DI-2 & 420 & & 34 & 105 & 664 & 15 \\
\hline & DI-3 & 350 & & 33 & 122 & 611 & 23 \\
\hline \multirow[t]{3}{*}{ High } & DI-1 & 490 & \multirow[t]{3}{*}{118} & 25 & 87 & 711 & 11 \\
\hline & DI-2 & 420 & & 23 & 97 & 653 & 19 \\
\hline & DI-3 & 350 & & 23 & 115 & 601 & 26 \\
\hline \multirow[t]{3}{*}{ Very high } & DI-1 & 560 & \multirow[t]{3}{*}{104} & 32 & 93 & 754 & 9 \\
\hline & DI-2 & 490 & & 30 & 103 & 697 & 16 \\
\hline & DI-3 & 420 & & 29 & 122 & 646 & 23 \\
\hline
\end{tabular}



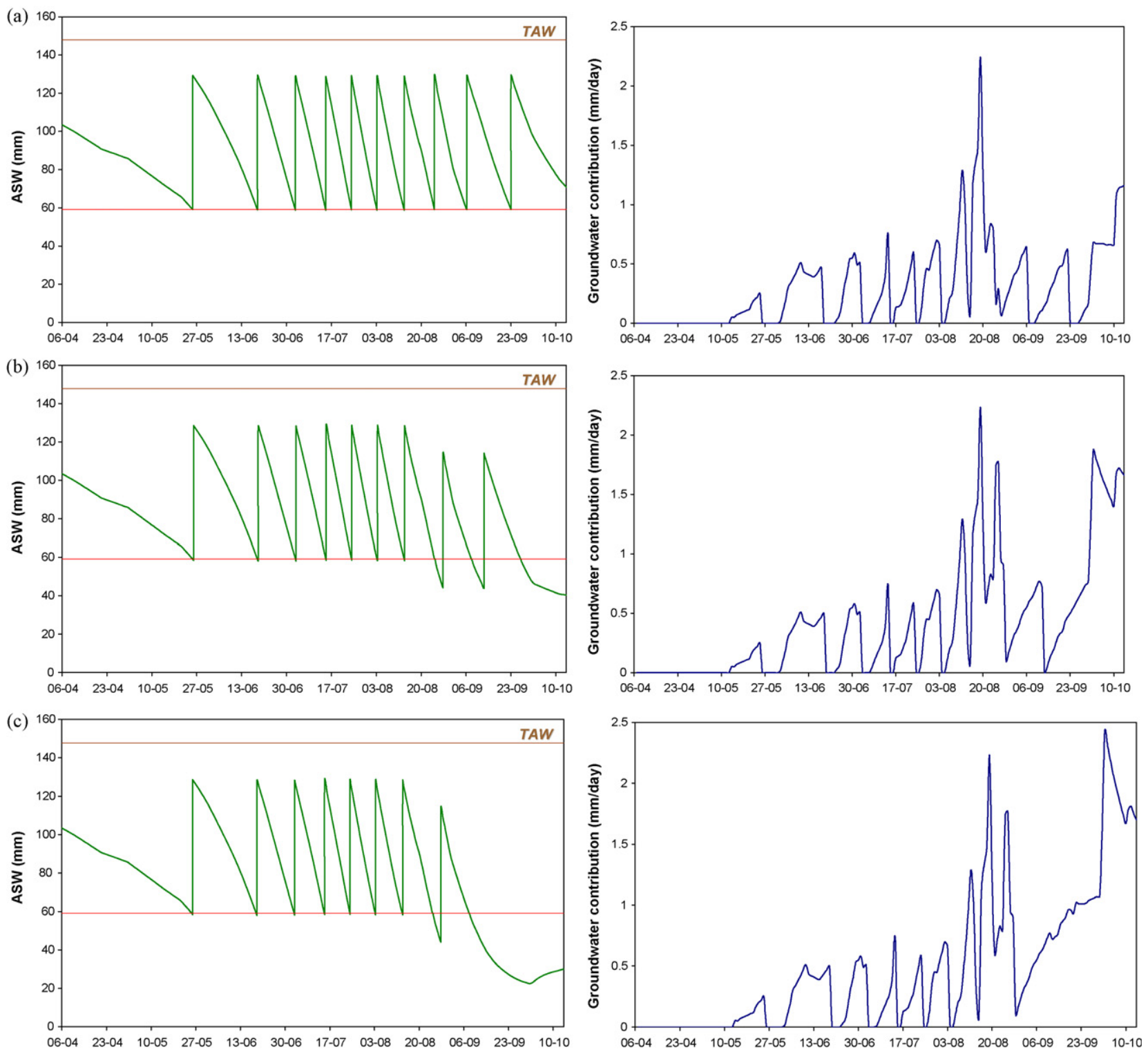

Fig. 6 - Seasonal variation of available soil water (on the left) and groundwater contribution (on the right) for various irrigation scheduling strategies (a) FI, (b) DI-RYL and (c) DI-1 for the very high demand scenario.

climatic demand scenario. Simulations refer to FI, DI-RYL, and DI-1 strategies. They show that GC is generally below $1 \mathrm{~mm} \mathrm{~d}^{-1}$ for the FI strategy and increases only during the peak demand period, when $\mathrm{ET}_{\mathrm{c}}$ is higher. Similar behavior occurs for the DI strategy but when comparing with FI the GC increases in the late season period, when soil water deficits occur; that GC increase is higher for DI-1 since the ASW deficit is higher. A similar behavior could be observed for DI-2 and DI3 but with a larger period and amounts of GC since the soil depletion is larger for these strategies.

\subsubsection{Water productivity and water saving}

Aiming at better comparing the irrigation strategies simulated for various scenarios of climatic demand, the respective water productivity and economic water productivity were estimated. Results in Table 13 show that WP and
EWP slightly increase when deficit irrigation strategies reduce the total water use by the cotton crop. However, these small increases in WP and EWP go with large decreases in yield and, consequently, in yield value.

Results show that WP is about the same for the FI and DIRYL strategies under average demand conditions but increases by less than $0.01 \mathrm{~kg} \mathrm{~m}^{-3}$ (Table 13). When the climatic demand is high and very high the WP also increases by less than $0.02 \mathrm{~kg} \mathrm{~m}^{-3}$ for the various DI strategies considered and all demand conditions. The EWP shows very small differences among all strategies. However, when comparing the DI-RYL strategy with the DI-3 it can be observed that increases smaller than $0.01 € \mathrm{~m}^{-3}$ correspond to decreases in yield value larger than $360 € \mathrm{ha}^{-1}$. This analysis indicates that selecting a water saving strategy based upon WP and/or EWP is not adequate. 
Table 13 - Simulated gross irrigation, total water use (TWU), yield, water productivity, yield value and economic water productivity for various irrigation strategies and selected climatic demand scenarios.

\begin{tabular}{|c|c|c|c|c|c|c|c|}
\hline $\begin{array}{l}\text { Demand } \\
\text { condition }\end{array}$ & $\begin{array}{l}\text { Irrigation } \\
\text { strategy }\end{array}$ & $\begin{array}{c}\text { Gross } \\
\text { irrigation }(\mathrm{mm})\end{array}$ & $\begin{array}{l}\text { TWU } \\
(\mathrm{mm})\end{array}$ & $\begin{array}{c}\text { Yield } \\
\left(\mathrm{kg} \mathrm{ha}^{-1}\right)\end{array}$ & $\begin{array}{c}\text { WP } \\
\left(\mathrm{kg} \mathrm{m}^{-3}\right)\end{array}$ & $\begin{array}{c}\text { Yield } \\
\text { value }\left(€ \mathrm{ha}^{-1}\right)\end{array}$ & $\begin{array}{c}\text { EWP } \\
\left(€ \mathrm{~m}^{-3}\right)\end{array}$ \\
\hline \multirow[t]{5}{*}{ Average } & FI & 933 & 1134 & 3769 & 0.332 & 1741 & 0.154 \\
\hline & DI-RYL & 930 & 1130 & 3758 & 0.332 & 1736 & 0.153 \\
\hline & DI-1 & 817 & 1046 & 3540 & 0.338 & 1635 & 0.156 \\
\hline & DI-2 & 700 & 944 & 3235 & 0.343 & 1494 & 0.158 \\
\hline & DI-3 & 583 & 845 & 2947 & 0.349 & 1361 & 0.161 \\
\hline \multirow[t]{5}{*}{ High } & FI & 1050 & 1212 & 3718 & 0.307 & 1718 & 0.142 \\
\hline & DI-RYL & 933 & 1134 & 3563 & 0.314 & 1646 & 0.145 \\
\hline & DI-1 & 817 & 1037 & 3300 & 0.318 & 1524 & 0.147 \\
\hline & DI-2 & 700 & 932 & 3000 & 0.322 & 1386 & 0.149 \\
\hline & DI-3 & 583 & 833 & 2732 & 0.328 & 1262 & 0.152 \\
\hline \multirow[t]{5}{*}{ Very high } & FI & 1168 & 1286 & 3767 & 0.293 & 1740 & 0.135 \\
\hline & DI-RYL & 1050 & 1221 & 3676 & 0.301 & 1698 & 0.139 \\
\hline & DI-1 & 933 & 1129 & 3443 & 0.305 & 1590 & 0.141 \\
\hline & DI-2 & 817 & 1025 & 3154 & 0.308 & 1457 & 0.142 \\
\hline & DI-3 & 700 & 928 & 2896 & 0.312 & 1338 & 0.144 \\
\hline
\end{tabular}

From the data collected and generated by modeling simulation it becomes evident that strategies leading to relatively high yield losses (DI-2 and DI-3, with RYL respectively larger than 15 and 23\%) should only be selected when the availability of irrigation water is very limited. However, it may be more appropriate to reduce the irrigated area and apply there a less stringent schedule such as DI-1 or DI-RYL. In fact, the RYL varies from 7 to $11 \%$ for the strategy DI-1 (Table 12) and from 1 to $4 \%$ for DI-RYL (Table 11) while the corresponding gross irrigation water savings range between 10 and 22\% for the high and very high demand scenarios.

The applicability of farmers' advise based upon an irrigation scheduling simulation model to help farmers adopt more adequate schedules has been demonstrated in the field (Cholpankulov et al., 2005). Therefore, results of this study may contribute to improve water saving irrigation in Central Asia, particularly in the Fergana region. However, a water saving policy requires the adoption of appropriate improvements in delivery scheduling and in furrow irrigation performance also as demonstrated by Horst et al. $(2005,2007)$.

\section{Conclusions}

The current cotton irrigation schedules practiced in Fergana show high non-beneficial water use as deep percolation and an inadequate use of the available soil water and groundwater contribution. To adopt water saving practices and controlling deep percolation improved irrigation schedules are required. These may be based on the use of simulation models adopting an improved crop parameterization obtained after appropriate calibration and validation as used in this study.

Model simulations were performed for two sets of data, one relative to daily data for the period when field experimentation, and model calibration and validation were performed (2001-2003), the other using a 10-day weather data set for 1970-2003. The first referred to wet years while the analysis with the second were performed for the average, dry and very dry years. Full irrigation and various deficit irrigation strategies were used. Results show that the groundwater contribution may play an important role since it represents up to $30 \%$ of the total water required by the crop when deficit irrigation strategies are adopted. Results also show that adopting deficit irrigation lead to better use of the available soil water and groundwater, i.e., considering the need to minimize yield decreases due to deficit irrigation, irrigation management must provide for maximizing the use of soil water and the groundwater contribution.

Comparing the simulated schedules it was observed that imposing heavy irrigation deficits leads to relatively high yield losses while the water productivity and the economic water productivity only slightly increase. These strategies are therefore questionable under an economic point of view, particularly when small farms are considered. Differently, mild deficit irrigation, producing relatively high irrigation water saving, up to $25 \%$, and small yield losses, not exceeding $11 \%$, may be considered for further improving irrigation in the study area. However, further improvements of the farm irrigation systems and the delivery schedules are also required.

\section{Acknowledgements}

The present studies were funded by the EU-INCO project ICA2CT-2000-10039. The support of the Agricultural Engineering Research Center (Project POCTI-SFA-7-245) is also acknowledged.

\section{R E F E R E N C E S}

Allen, R.G., Pereira, L.S., Raes, D., Smith, M., 1998. Crop evapotranspiration. Guidelines for computing crop water requirements. FAO Irrig. Drain. Pap. 56, FAO, Rome, 300 pp.

Barker, G.L., 1982. Equation for estimating cotton preharvest losses. Trans. ASAE 25 (2), 271-276 282.

Barker, G.L., 1996. Equilibrium moisture content of cotton plant components. J. Agric. Eng. Res. 63, 353-364.

Barker, G.L., Laird, J.W., 1993. Drying and humidification rates for cotton lint. Trans. ASAE 36 (6), 1555-1562. 
Bhattarai, S.P., McHugh, A.D., Lotz, G., Midmore, D.J., 2006. The response of cotton to subsurface drip and furrow irrigation in a vertisol. Exp. Agric. 42 (1), 29-49.

Bruce, R.R., Shipp, C.D., 1962. Cotton fruiting as affected by soil moisture regime. Agron. J. 61, 15-18.

Cancela, J.J., Cuesta, T.S., Neira, X.X., Pereira, L.S., 2006. Modelling for improved irrigation water management in a temperate region of Northern Spain. Biosyst. Eng. 94 (1), 151-163.

Cholpankulov, E.D., Inchenkova, O.P., Paredes, P., Pereira, L.S., 2005. Strategies for irrigation scheduling to cope with water scarcity. In: Pereira, L.S., Dukhovny, V.A., Horst, M.G. (Eds.), Irrigation Management for Combating Desertification in the Aral Sea Basin. Assessment and Tools. Vita Color Publish, Tashkent, pp. 125-147.

Cholpankulov, E.D., Inchenkova, O.P., Paredes, P., Pereira, L.S., 2008. Cotton irrigation scheduling in Central Asia: Model calibration and validation with consideration of groundwater contribution. Irrig. Drain. 57, 516-532.

Dalton, P., Raine, S., Broadfoot, K., 2001. Best management practices for maximizing whole farm irrigation efficiency in the cotton industry. Final report for CRDC Project NEC2C. National Centre for Engineering in Agriculture Publication 179707/2, USQ Toowoomba.

Dagdelen, N., Ersel, Y., Sezgin, F., Gurbuz, T., 2006. Water-yield relation and water use efficiency of cotton (Gossypium hirsutum L.) and second crop corn (Zea mays L.) in western Turkey. Agric. Water Manage. 82 (1-2), 63-85.

DeTar, W.R., 2008. Yield and growth characteristics for cotton under various irrigation regimes on sandy soil. Agric. Water Manage. 95, 69-76.

Domullodjanov, Kh.D., 1983. Recommendations for Calculating Irrigation Regimes when Programming Yields in Cotton Rotation in Tajik SST. SANIIRI, Dushanbe, 74 pp. (in Russian)

Doorenbos, J., Kassam, A.H., 1979. Yield Response to Water. FAO Irrig. Drain. Paper 33, FAO, Roma.

Dukhovny, V.A., Yakubov, Kh., Umarov, P.D., 2005. Drainage and salinity control: review of related problems in Central Asia. In: Pereira, L.S., Dukhovny, V.A., Horst, M.G. (Eds.), Irrigation Management for Combating Desertification in the Aral Sea basin. Assessment and Tools. Vita Color Publisher, Tashkent, pp. 247-268.

Ertek, A., Kanber, R., 2003. Effects of different drip irrigation programs on boll number and shedding percentage and yield of cotton. Agric. Water Manage. 60, 1-11.

Falkenberg, N.R., Giovanni, P., Cothren, J.T., Leskovar, D.I., Rush, C.M., 2007. Remote sensing of biotic and abiotic stress for irrigation management of cotton. Agric. Water Manage. 87 (1), 23-31.

FAO, 2004. General Summary for the Countries of the Former Soviet Union. AQUASTAT, FAO, Rome. (http://www.fao.org/).

FAS-USDA, 2002. Uzbekistan trip report 11/2002. USA, 10 pp. (http://www.fas.usda.gov/).

Fortes, P.S., Platonov, A.E., Pereira, L.S., 2005. GISAREG-A GIS based irrigation scheduling simulation model to support improved water use. Agric. Water Manage. 77, 159-179.

Gerik, T.J., Faver, K.L., Thaxton, P.M., El-Zik, K.M., 1996. Late season water stress in cotton. I: Plant growth, water use, and yield. Crop Sci. 36, 914-921.

Gibb, D., Neilsen, J., Constable, G., 2004. Cotton growth responses to water stress. In: WATERpak, A Guide for Irrigation Management in Cotton, Cotton Catchment Communities, Austr. Cotton Res. Inst., pp. 117-126.

Grimes, D.W., Yamada, H., 1982. Relation of cotton growth and yield to minimum leaf water potential. Crop Sci. 22, 134-139.
Grimes, D.W., Yamada, H., Dickens, W.L., 1969. Functions for cotton (Gossypium hirsutum L.) production from irrigation and nitrogen fertilization variables. I: Yield and evapotranspiration. Agron. J. 61, 769-773.

Horst, M.G., Shamutalov, Sh.S., Pereira, L.S., Gonçalves, J.M., 2005. Field assessment of the water saving potential with furrow irrigation in Fergana, Aral Sea Basin. Agric. Water Manage. 77, 210-231.

Horst, M.G., Shamutalov, Sh.Sh., Gonçalves, J.M., Pereira, L.S., 2007. Assessing impacts of surge-flow irrigation on water saving and productivity of cotton. Agric. Water Manage. 87 (2), 115-127.

Howell, T.A., Evett, S.R., Tolk, J.A., Schneider, A.D., 2004. Evapotranspiration of full-, deficit-irrigated, and dryland cotton on the northern Texas High Plains. J. Irrig. Drain. Eng. 130 (4), 277-285.

Jackson, E.B., Tilt, P.A., 1968. Effects of irrigation intensity and nitrogen level on the performance of eight varieties of upland cotton, Gossypium hirsutum L. Agron. J. 60, 13-17.

Karam, F., Rafic, L., Randa, M., Daccache, A., Mounzer, O., Rouphael, Y., 2006. Water use and lint yield response of drip irrigated cotton to length of season. Agric. Water Manage. 85 (3), 287-295.

Laktaev, N., 1978. Cotton Irrigation. Kolos Publ., Moscow (in Russian).

Liu, Y., Pereira, L.S., Fernando, R.M., 2006. Fluxes through the bottom boundary of the root zone in silty soils: parametric approaches to estimate groundwater contribution and percolation. Agric. Water Manage. 84, 27-40.

Pereira, L.S., 2007. Relating water productivity and crop evapotranspiration. In: Lamaddalena, N., Shatanawi, M., Todorovic, M., Bogliotti, C., Albrizio, R. (Eds.), Water Use Efficiency and Water Productivity: Proceedings of WASAMED Workshop, Amman, Jordan, October 2005, Options Méditerranéennes Ser. B 57, 31-50.

Pereira, L.S., Dukhovny, V.A., Horst, M.G. (Eds.), 2005. Irrigation Management for Combating Desertification in the Aral Sea basin. Assessment and Tools. Vita Color Publisher, Tashkent.

Pereira, L.S., Oweis, T., Zairi, A., 2002. Irrigation management under water scarcity. Agric. Water Manage. 57, 175-206.

Pereira, L.S., Teodoro, P.R., Rodrigues, P.N., Teixeira, J.L., 2003. Irrigation scheduling simulation: the model ISAREG. In: Rossi, G., Cancelliere, A., Pereira, L.S., Oweis, T., Shatanawi, M., Zairi, A. (Eds.), Tools for Drought Mitigation in Mediterranean Regions. Kluwer, Dordrecht, pp. 161-180.

Pereira, L.S., Gonçalves, J.M., Dong, B., Mao, Z., Fang, S.X., 2007. Assessing basin irrigation and scheduling strategies for saving irrigation water and controlling salinity in the Upper Yellow River Basin, China. Agric. Water Manage. 93 (3), 109-122.

Pettigrew, W.T., 2004a. Moisture deficit effects on cotton lint yield, yield components, and boll distribution. Agron. J. 96, 377-383.

Pettigrew, W.T., 2004b. Crop physiology and metabolism: physiological consequences of moisture deficit stress in cotton. Crop Sci. 44 (4), 1265-1272.

Popova, Z., Pereira, L.S., 2008. Irrigation scheduling for furrow irrigated maize under climate uncertainties in the Thrace Plain, Bulgaria. Biosyst. Eng. 99, 587-597.

Popova, Z., Eneva, S., Pereira, L.S., 2006. Model validation, crop coefficients and yield response factors for maize irrigation scheduling based on long-term experiments. Biosyst. Eng. 95 (1), 139-149.

Shreder, V.R., Vasiliev, I.K., Trunova, T.A., 1977. Hydromodule zoning and calculation of irrigation norms for cotton under arid conditions. In: Kadirov, A.A. (Ed.), Design and Efficiency of Irrigation and Drainage System Performance in Central Asia, vol. 8SANIIRI, Tashkent, pp. 28-41 (in Russian). 
Smith, M., Pereira, L.S., Berengena, J., Itier, B., Goussard, J., Ragab, R., Tollefson, L., Van Hoffwegen, P. (Eds.), 1996. Irrigation Scheduling: From Theory to Practice. FAO Water Report 8, FAO, Rome, 384 pp.

Stewart, J.L., Hanks, R.J., Danielson, R.E., Jackson, E.B., Pruitt, W.O., Franklin, W.T., Riley, J.P., Hagan, R.M., 1977. Optimizing Crop Production Through Control of Water and Salinity Levels in the Soil. Utah Water Res. Lab. Rep. PRWG151-1, Utah St. Univ., Logan.
Teixeira, J.L., Pereira, L.S., 1992. ISAREG, an irrigation scheduling model. ICID Bull. 41 (2), 29-48.

Turner, N.C., Hearn, A.B., Begg, J.E., Constable, G.A., 1986. Cotton (Gossypium hirsutum L.) physiological and morphological responses to water deficits and their relationships to yield. Field Crops Res. 14, 153-170.

Yazar, A., Sezen, S.M., Sesveren, S., 2002. LEPA and trickle irrigation of cotton in the southeast Anatolia project (GAP) area in Turkey. Agric. Water Manage. 54, 189-203. 